Studies in Military and Strategic History

General Editor: Michael Dockrill, Professor of Diplomatic History, King's College London

Published titles include:

Martin Alexander and William Philpott (editors)

ANGLO-FRENCH DEFENCE RELATIONS BETWEEN THE WARS

Christopher M. Bell

THE ROYAL NAVY, SEAPOWER AND STRATEGY BETWEEN THE WARS

Peter Bell

CHAMBERLAIN, GERMANY AND JAPAN, 1933-34

Antony Best

BRITISH INTELLIGENCE AND THE JAPANESE CHALLENGE IN ASIA, 1914-41

Philippe Chassaigne and Michael Dockrill (editors)

ANGLO-FRENCH RELATIONS, 1898-1998

From Fashoda to Jospin

Michael Dockrill

BRITISH ESTABLISHMENT PERSPECTIVES ON FRANCE, 1936-40

Michael Dockrill and John Fisher

THE PARIS PEACE CONFERENCE, 1919

Peace Without Victory?

Robert Frazier

ANGLO-AMERICAN RELATIONS WITH GREECE

The Coming of the Cold War, 1942-47

John P. S. Gearson

HAROLD MACMILLAN AND THE BERLIN WALL CRISIS, 1958-62

John Gooch

ARMY, STATE AND SOCIETY IN ITALY, 1870-1915

G. A. H. Gordon

BRITISH SEA POWER AND PROCUREMENT BETWEEN THE WARS

A Reappraisal of Rearmament

Raffi Gregorian

THE BRITISH ARMY, THE GURKHAS AND COLD WAR STRATEGY IN THE FAR EAST, 1947-1954

Stephen Hartley

THE IRISH QUESTION AS A PROBLEM IN BRITISH FOREIGN POLICY, 1914-18

Brian Holden Reid

J. F. C. FULLER: Military Thinker

Ashley Jackson

WAR AND EMPIRE IN MAURITIUS AND THE INDIAN OCEAN 
Stewart Lone

JAPAN'S FIRST MODERN WAR

Army and Society in the Conflict with China, 1894-95

Thomas R. Mockaitis

BRITISH COUNTERINSURGENCY, 1919-60

Bob Moore and Kent Fedorowich

THE BRITISH EMPIRE AND ITS ITALIAN PRISONERS OF WAR, 1940-47

T. R. Moreman

THE ARMY IN INDIA AND THE DEVELOPMENT OF FRONTIER WARFARE, 1849-1947

Kendrick Oliver

KENNEDY, MACMILLAN AND THE NUCLEAR TEST-BAN DEBATE, 1961-63

P. G. A. Orders

BRITAIN, AUSTRALIA, NEW ZEALAND AND THE CHALLENGE OF THE UNITED STATES, 1939-46

A Study in International History

Elspeth Y. O'Riordan

BRITAIN AND THE RUHR CRISIS

G. D. Sheffield

LEADERSHIP IN THE TRENCHES

Officer-Man Relations, Morale and Discipline in the British Army in the Era of the First World War

Adrian Smith

MICK MANNOCK, FIGHTER PILOT

Myth, Life and Politics

Martin Thomas

THE FRENCH NORTH AFRICAN CRISIS

Colonial Breakdown and Anglo-French Relations, 1945-62

Simon Trew

BRITAIN, MIHAILOVIC AND THE CHETNIKS, 1941-42

Steven Weiss

ALLIES IN CONFLICT

Anglo-American Strategic Negotiations, 1938-44

Studies in Military and Strategic History

Series Standing Order ISBN 978-0-333-71046-3

(outside North America only)

You can receive future titles in this series as they are published by placing a standing order. Please contact your bookseller or, in case of difficulty, write to us at the address below with your name and address, the title of the series and the ISBN quoted above.

Customer Services Department, Macmillan Distribution Ltd, Houndmills, Basingstoke, Hampshire RG21 6XS, England 


\section{Britain, Australia,}

New Zealand and the

Challenge of the United

States, 1939-46

A Study in International History

P. G. A. Orders 


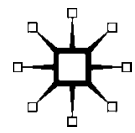

(C) P. G. A. Orders 2003

Softcover reprint of the hardcover 1st edition 2003 978-0-333-77500-4

All rights reserved. No reproduction, copy or transmission of this publication may be made without written permission.

No paragraph of this publication may be reproduced, copied or transmitted save with written permission or in accordance with the provisions of the Copyright, Designs and Patents Act 1988, or under the terms of any licence permitting limited copying issued by the Copyright Licensing Agency, 90 Tottenham Court Road, London W1T 4LP.

Any person who does any unauthorised act in relation to this publication may be liable to criminal prosecution and civil claims for damages.

The author has asserted his right to be identified as the author of this work in accordance with the Copyright, Designs and Patents Act 1988.

First published 2003 by

PALGRAVE MACMILLAN

Houndmills, Basingstoke, Hampshire RG21 6XS and

175 Fifth Avenue, New York, N. Y. 10010

Companies and representatives throughout the world

PALGRAVE MACMILLAN is the global academic imprint of the Palgrave

Macmillan division of St. Martin's Press, LLC and of Palgrave Macmillan Ltd. Macmillan ${ }^{\circledR}$ is a registered trademark in the United States, United Kingdom and other countries. Palgrave is a registered trademark in the European Union and other countries.

ISBN 978-1-349-41668-4

ISBN 978-0-230-28907-9 (eBook)

DOI 10.1057/9780230289079

This book is printed on paper suitable for recycling and made from fully managed and sustained forest sources.

A catalogue record for this book is available from the British Library.

Library of Congress Cataloging-in-Publication Data

Orders, P. G. A., 1968-

Britain, Australia, New Zealand, and the challenge of the United States, 1939-46: a study in international history / P. G. A. Orders.

p. cm.-(Studies in military and strategic history)

Includes bibliographical references and index.

ISBN 978-1-349-41668-4

1. Commonwealth countries-Foreign relations-Great Britain. 2. Great Britain-Foreign relations-Commonwealth countries. 3. Commonwealth countries-Foreign relations-United States 4. United States-Foreign relations-Commonwealth countries. 5. United States-Foreign relations-Great Britain. 6. Great Britain-Foreign relations-United States. 7. International relations-History-20th century. 8. History, Modern-20th century. I. Title. II. Studies in military and strategic history (Palgrave Macmillan (Firm))

DA18.2.G7 O73 2002

327.41093'09'043-dc

212002072329

$\begin{array}{llllllllll}10 & 9 & 8 & 7 & 6 & 5 & 4 & 3 & 2 & 1\end{array}$

$\begin{array}{llllllllll}12 & 11 & 10 & 09 & 08 & 07 & 06 & 05 & 04 & 03\end{array}$ 


\section{Contents}

Acknowledgements vi

Maps viii

Introduction $\quad 1$

1 Prelude: Interwar Rivalry 5

2 Atlantic Rapprochement - Pacific Rivalry 24

3 Defeat and Recovery $\quad 57$

4 Anzaxis $\quad 86$

5 Planning for Peace 128

6 Bargaining for Security 153

$\begin{array}{ll}\text { Epilogue } & 184\end{array}$

$\begin{array}{lr}\text { Conclusion } & 193\end{array}$

Notes and References $\quad 202$

$\begin{array}{ll}\text { Select Bibliography } & 241\end{array}$

$\begin{array}{ll}\text { Index } & 251\end{array}$ 


\section{Acknowledgements}

I have accumulated a vast number of debts en route to completing this book. Special thanks are due to Carl Bridge, Michael Dockrill, C. C. Eldridge, Anthony Low, my former history teacher Roger Jones, and above all my doctoral supervisor, David Reynolds. In Canberra I enjoyed the hospitality and conversation of Frank Cain, David Lees, John McCarthy, and Chris Waters. Wayne Reynolds welcomed me into his home in Newcastle, New South Wales, cast light on Doc Evatt, and introduced me to the vineyards of the Hunter Valley. I doubt any of these senior academics will remember me quite as clearly as I recall them, but I want each of them to know that their help and kindness was greatly appreciated. None is responsible for what follows.

The financial largesse of various organizations enabled me to pursue research in Australia, Britain, Canada, the United States and New Zealand. My main source of support throughout my doctoral studies was the British Academy. I also benefited from the generosity of the BritainAustralia Society, which awarded me a Northcote Visiting Scholarship, and the Franklin D. Roosevelt Library Institute, which awarded me a Lubin-Winant Research Fellowship. Additional support was provided by Downing College, the Harry S. Truman Library and the Smuts Memorial Fund.

My thanks go to the staff of the following institutions: the National Archives of Australia, Canberra; the Bodleian Library, Oxford; the British Library, London; the British Library of Political and Economic Science, London; the Franklin D. Roosevelt Library, Hyde Park, New York; the Harry S. Truman Library, Independence, Missouri; the House of Lords Records Office, London; the Imperial War Museum, London; the National Archives of Canada, Ottawa; the National Library of Australia, Canberra; the New Zealand National Archives, Wellington; the Public Record Office, Kew; the United States National Archives, Washington D.C.; University Library, Cambridge; and the Washington National Records Center, Suitland, Maryland. I wish to express gratitude to Lady Batterbee for donating the papers of her late husband, Sir Harry Batterbee, to Rhodes House Library, Oxford.

The support of family and friends enabled me to see this project through to publication. My father, Arnold Orders, was a source of tremendous encouragement and inspiration. He taught me the value of 
education and would have been proud to see the results of my research in print. This book is dedicated to his memory and to Jayne Barrett and Maureen Orders, both of whom put up with me and somehow still keep smiling.

Maesteg, March 2002 


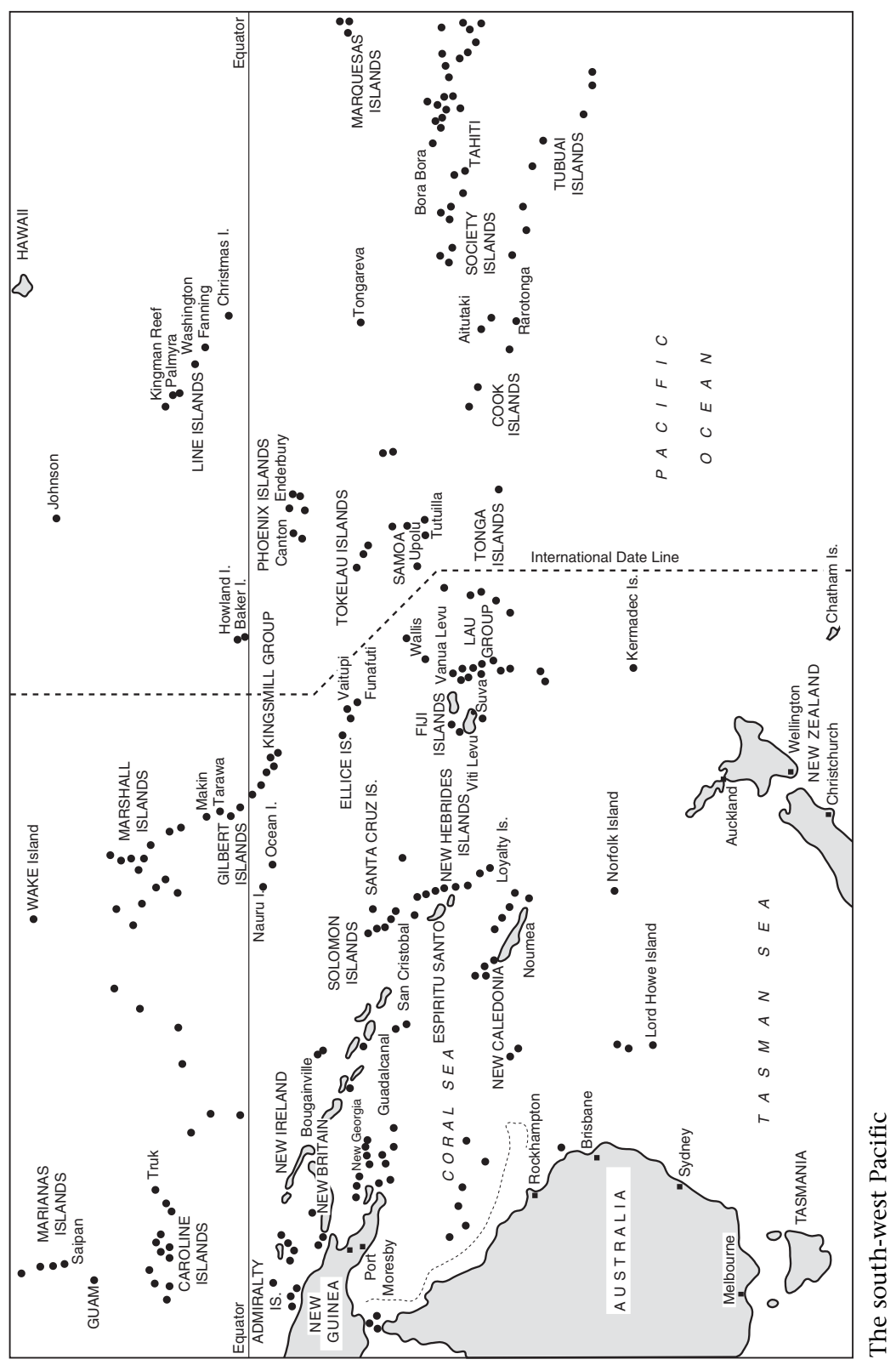




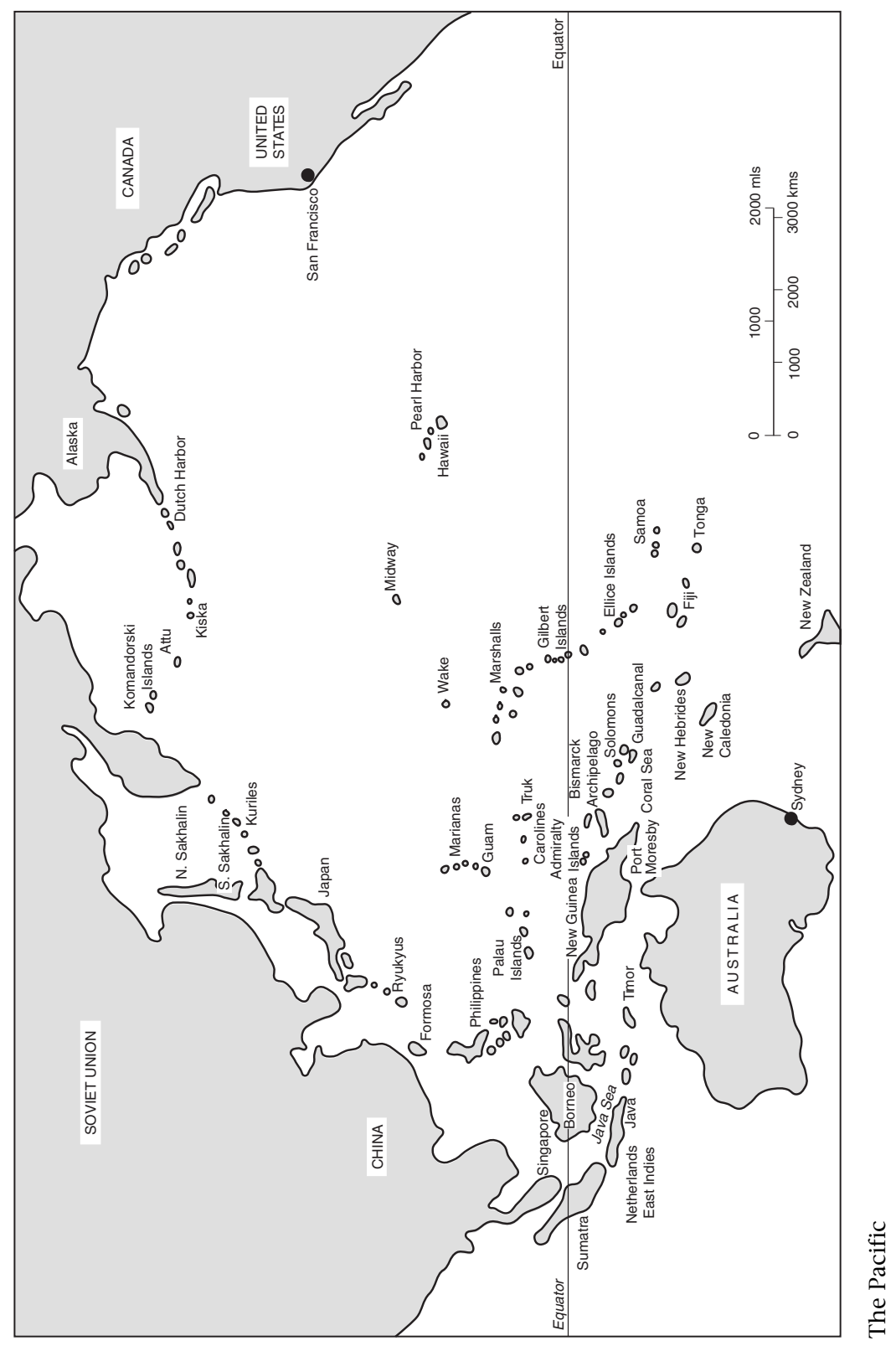

